Marek Krynke ${ }^{1}$, Manuela Ingaldi ${ }^{2}$

\title{
DOSKONALENIE PROCESÓW PRZY PRODUKCJI WYBRANYCH CZEŚSCI SAMOCHODOWYCH
}

\begin{abstract}
Streszczenie: W niniejszym rozdziale badaniu zostało poddane przedsiębiorstwo branży motoryzacyjnej. W analizie skupiono się na identyfikacji niezgodności występujących podczas produkcji wybranej części samochodowej oraz metodach doskonalenia jej jakości. Do określenie struktury niezgodności wyrobu wykorzystano diagram Ishikawy, oraz diagram Pareto-Lorenza. Dokonano kwantyfikacji przyczyn niezgodności wykorzystując metodę FMEA oraz zrealizowano proces doskonalenia jakości analizowanego wyrobu w oparciu o wymagania klienta stosując metodę QFD.
\end{abstract}

Słowa kluczowe: jakość, doskonalenie, Ishikava, Pareto-Lorenz, FMEA, QFD.

\section{Prezentacja przedsiębiorstwa branży motoryzacyjnej}

Przedsiębiorstwo, w którym analizie poddano proces produkcyjny jest obecnie jednym $\mathrm{z}$ europejskich liderów w dziedzinie badań, rozwoju, produkcji i dystrybucji komponentów i systemów z gumy i tworzyw termoplastycznych do zastosowań w motoryzacji, kolei i innych gałęziach przemysłu. Wśród wytwarzanych produktów w obecnej chwili w przedsiębiorstwie należą następujące elementy:

- antywibracyjne i resory pneumatyczne,

- przewody hamulcowe,

- elementy gumowe techniczne,

- profile z tworzyw termoplastycznych,

- uszczelki gumowe,

- uszczelniacze.

${ }^{1}$ Dr inż., Czestochowa University of Technology, Department of Management, Division of Production Engineering, e-mail: krynke@zim.pcz.pl

${ }^{2}$ Dr inż., Czestochowa University of Technology, Department of Management, Division of Production Engineering, e-mail: manuela@gazeta.pl 
Polityka jakości przedsiębiorstwa jest zgodna $\mathrm{z}$ wymogami jakościowymi normy ISO 9001: 2008, a wszelkie wyroby $\mathrm{z}$ gumy produkowane $\mathrm{z}$ przeznaczeniem na rynek produktów automotive wytwarzane są zgodnie z wymogami systemu ISO/TS16949:2002.

Priorytetem przedsiębiorstwa jest zaspokajanie wszelkich, wymagań swoich klientów. Ważna $\mathrm{z}$ punktu widzenia firmy jest terminowość dostaw, oraz wytwarzanie wysokiej jakości produktów przy konkurencyjnych cenach. Jednym z celów firmy jest poszerzanie oferty produktów, doskonalenie procesu produkcyjnego i zdobywanie szerszego rynku (ŁUNARSKI J. 2008, STABRYŁA A. 1998).

Przedsiębiorstwo posiada własne zasady jakości. Najważniejsze z nich mówią o ciągłym doskonaleniu Systemu Zarządzania Jakością, standaryzacji, organizowaniu miejsca pracy, jakości integralnej, 5s (PNEN ISO 9001:2009).

\section{Proces produkcyjny wybranego produktu}

Podmiotem badań jest tłumik drgań montowany na amortyzatorach. Wchodzi on w skład elementów antywibracyjnych. Elementy antywibracyjne są to produkty, które zazwyczaj wykonywane są $\mathrm{z}$ gumy bądź metalu. Tworzą one elastyczne połączenie pomiędzy ciałami sztywnymi. Do ich zadań należy thumienia względnego ruchu i jednocześnie ograniczenie przenoszenia drgań i dźwięku. Są one używane do samochodów oraz wszelkiego typu pojazdów przemysłowych.

Pierwszym etapem produkcji tego wyrobu jest przygotowanie odpowiedniego materiału, który będzie brał udział w produkcji. W tym przypadku jest to metalowy kołnierz spełniający odpowiednie wymagania tj. określony kształt, wymiary, otwory mocujące. Wybrany element zostaje transportowany na palecie za pomocą wózka widłowego do hali produkcyjnej na odpowiednie stanowiska pracy. Następnie kołnierze są wykładane na taśmociąg, gdzie sprawdzana jest przyczepność oraz położenie komponentu. Kolejną operacją jest $100 \%$ kontrola przez system Poka Yoke. Wadliwe, nie wymiarowe kołnierze są odrzucane 
i złomowane. Po kontroli elementy wędrują do stanowiska gdzie następuje łączenie metalowego kołnierza $\mathrm{z}$ tuleją, która ma za zadanie amortyzować drgania, $\mathrm{z}$ tego stanowiska gotowy produkt wędruje na magazyn. Na rysunku 1 przedstawiono schemat procesu wytwórczego w ujęciu technologicznym.

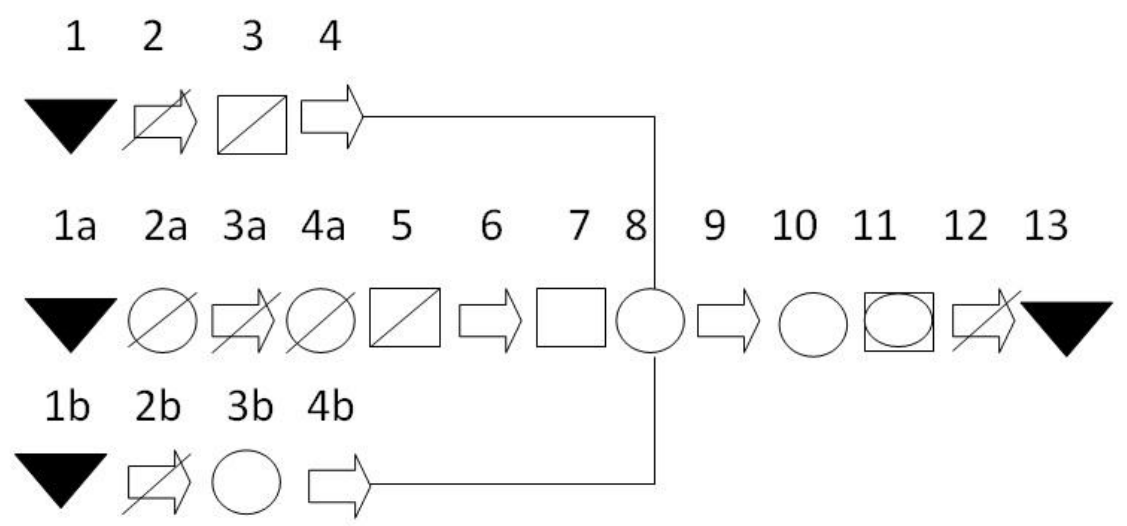

Rys. 1. Proces wytwórczy w ujęciu technologicznym thumika drgań amortyzatora

Źródło: opracowanie własne

Proces technologiczny tłumika drgań składa się z następujących etapów: 1. Magazynowanie tulejek, 1a. Magazynowanie kołnierzy, 1b. Magazynowanie tulejek, 2. Transport tulejki z magazynu na hale produkcyjną, 2a. Przygotowanie kołnierzy, 2b. Transport gumy z magazynu do stanowiska wykrawania, 3. Wizualna kontrola jakości tulejek, 3a. Transport kołnierzy na hale produkcyjną, 3b. Wycinanie gumowych krążków, 4. Transport tulejek na stanowisko łączenia elementów, 4a. Ładowanie kołnierzy na taśmociąg, 4b. Kontrola wymiarów wyciętych krążków, 5. Kontrola przyczepności, 5a. Transport krążków na stanowisko montażu elementu gumowego z kołnierzem, 6. Transport miedzy operacyjny, 7. Kontrola Poka Yoke kołnierzy, 
8. Montaż kołnierza $\mathrm{z}$ tulejką, 9. Transport miedzy operacyjny, 10. Montaż śrub, 11. Łączenie śrubą kołnierza wraz z tulejką/kontrola Poka Yoke, 12. Transport wyrobów gotowych do magazynu wyrobów gotowych, 13. Magazynowanie.

\section{Nadzór nad wyrobem niezgodnym}

Każdy produkowany wyrób posiada dla siebie kartę wyrobu. Zawarte w niej informacje dotyczą między innymi wymiarów oraz ich dopuszczalne odchylenia. Kolejnym dokumentem jest karta częstotliwości pomiarów. Określa ona przyrząd jakim zostały zrobione pomiary, częstotliwość pomiarów oraz rodzaj pomiaru. Wyroby gotowe w zależności od klienta badane są według określonych zasad w procedurze. To klient decyduje jaka ilość sztuk musi zostać zbadana. Minimum jakie wykonuje firma to 10 sztuk z każdej partii produkcji. Wyniki kontroli zapisywane są w karcie finałowej final examination, która często wysyłana jest do klienta jako dowód, że dane badanie zostało wykonane. Struktura karty finałowej zawiera trzy grupy wad:

- wada mało znacząca,

- wada dopuszczalna,

- wada krytyczna.

Ilość niezgodności, która może wystąpić w wylosowanej próbie, jest z góry określona dla każdej grupy wad. Produkt nie może posiadać żadnej wady krytycznej. Wada dopuszczalna może wystąpić raz, a wada znacząca maksymalnie pięć razy. Przykładowe rodzaje wad oraz ich przyporządkowanie do poszczególnych grup zostały zestawione w tablicy 1. Podczas sprawdzania jakości produktów znajdujących się na linii produkcyjnej i stwierdzeniu $\mathrm{w}$ nich niezgodności, operator po wypełnieniu karty kontrolnej powinien poinformować lidera o zaistniałej sytuacji. Jeśli operator uzna, że wyrobów niezgodnych jest za dużo powinien, zatrzymać linie i jak najszybciej zgłosić do kierownika zmiany. Sprawdzaniu podlegają również automaty sortujące wyroby z systemem Poka Yoke (BoRKOWsKI S., UlEWICZ R. 2008). Jeśli zostanie stwierdzona sytuacja, w której system wykrywa więcej niż 5 sztuk pod 
rząd automat zatrzymuje się i daje sygnał dźwiękowy. Operator wraz z liderem oceniają sytuację i wprowadzają działania korygujące.

Tablica 1. Rodzaje wystepujących wad w przedsiębiorstwie

\begin{tabular}{|l|l|l|}
\hline Lp. & Rodzaj wady & Wada \\
\hline 1. & Wada dopuszczalna & Zabrudzenia zewnętrzne kołnierza \\
\hline 2. & Wada dopuszczalna & Zarysowania kołnierza \\
\hline 3 & Wada krytyczna & Rdza \\
\hline 4. & Wada krytyczna & Pęcherzyki na kołnierzach \\
\hline 5. & Wada krytyczna & Wyszczerbienia tulei \\
\hline 6. & Wada mało znacząca & Smugi \\
\hline 7. & Wada krytyczna & Brak otworów na kołnierzu \\
\hline 8. & Wada krytyczna & Pęknięcia gumy \\
\hline 9. & Wada dopuszczalna & Wyszczerbienia gumy \\
\hline 10. & Wada krytyczna & Niewłaściwe wymiary kołnierza \\
\hline 11. & Wada krytyczna & Niewłaściwe wymiary tulei \\
\hline
\end{tabular}

Źródto: opracowanie własne

\section{Struktura niezgodności części samochodowych}

W celu identyfikacji przyczyn niezgodności wykorzystuje się diagram Ishikawy. Jest on jednym z częściej stosowanych narzędzi w zarządzaniu jakością. Jego istotą jest graficzna prezentacja analizy wzajemnych powiązań przyczyn wywołujących określony problem. Analizowanie diagramu pozwala wyodrębnić najważniejsze przyczyny, które mają wpływ na poziom jakości, a co za tym idzie dzięki niemu można wyodrębnić przyczyny i określić działania korygującozapobiegawcze (BORKOWSKI S. 2004).

Diagram Ishikawy opracowany dla problemu niskiej jakości nowego produktu produkowanego przez badane przedsiębiorstwo przedstawiono na rys. 2. Zaprezentowany diagram grupuje przyczyny problemów i obrazuje wzajemne powiązanie między nimi. W ten sposób można zauważyć, iż największy wpływ na jakość badanego produktu mają 
2 grupy przyczyn: metoda (40\%) i materiał (30\%). Na ich podstawie określono 5 głównych źródeł wpływających na jakość produktu.

- nie stosowanie się do procedur,

- duża zależność od umiejętności operatora,

- nie udoskonalany standard pracy,

- $\quad$ wadliwe części, komponenty (od dostawców),

- niska jakość materiałów.

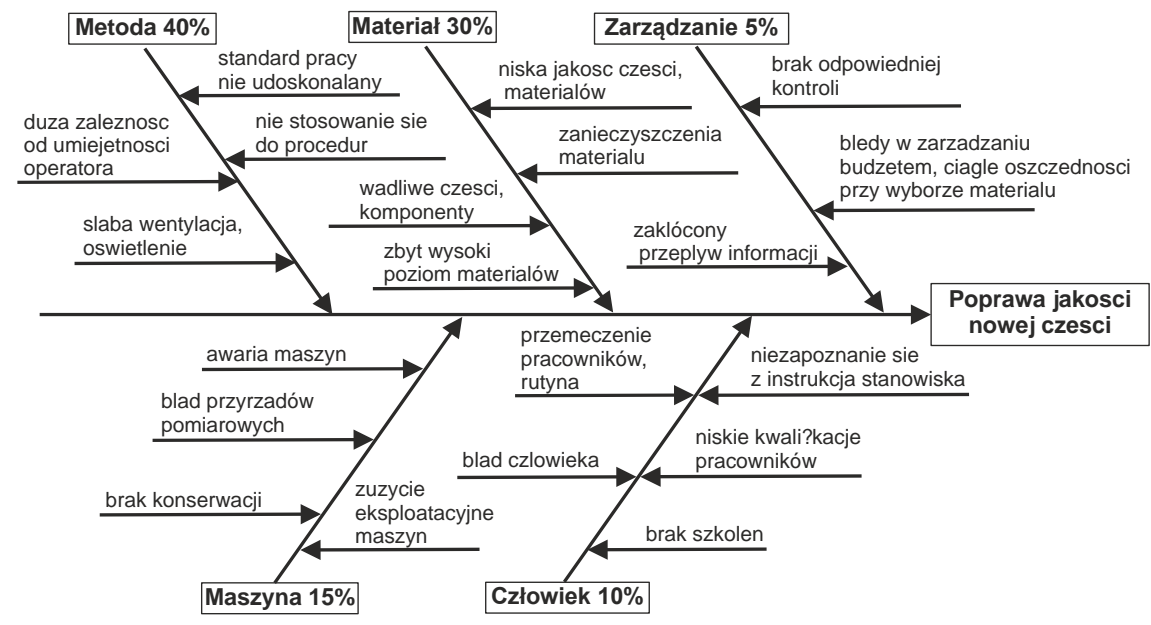

Rys. 2. Diagram Ishikawy

Źródto: opracowanie własne

Identyfikacja najważniejszych przyczyn umożliwia opracowanie zakresu działań w celu planowania jakości nowego produktu. Plan ten obejmuje nie tylko określenie metod kontroli wykrytych w wskazanych miejscach, ale także podjęcie konkretnych działań w celu zniwelowania przyczyn (BORKOWSKI S., KLIMECKA-TATAR D., KRYNKE M. 2012).

W tym celu zaproponowano działania korygująco-zapobiegawcze takie jak :

- dodatkowe szkolenia dla operatorów,

- dodatkowe audyty procesu, 
- tworzenie planów udoskonalenia procesów przez pracowników,

- audyty u dostawców, zwrócenie uwagi na jakość materiałów,

- zwiększenie kontroli wejściowej,

- doskonalenie standaryzacji.

Ilościowego przedstawienia problemów jakościowych dokonano w oparciu o diagram Pareto-Lorenza. Niezgodności występujące podczas produkcji badanego wyrobu w firmie dzieli się na:

- Niezgodności krytyczne:

○ $\operatorname{rdza}(\mathrm{N} 1)$,

- pęcherzyki na kołnierzach (N2),

$\circ$ wyszczerbienia tulei (N3),

○ brak otworów na kołnierzu (N4),

○ pęknięcia gumy (N6),

- Wady dopuszczalne:

○ zabrudzenia zewnętrzne kołnierza (N7),

○ zarysowania kołnierza (N8),

- Wady małoznaczące:

○ Smugi (N5).

$\mathrm{Na}$ rysunku 3 przedstawiono diagram Pareto-Lorenza za pomocą którego w przejrzysty sposób uszeregowano ilościowo liczbę poszczególnych niezgodności występujących podczas produkcji tłumika drgań amortyzatora.

Z przedstawionego diagramu (rys. 3) widać, że za 74,57\% wszystkich niezgodności $\mathrm{w}$ procesie produkcyjnym badanego wyrobu odpowiadają trzy niezgodności tj. pęknięcia gumy $(36,36 \%)$, pęcherzyki na kołnierzach $(29,12 \%)$ oraz wyszczerbienia tulei $(9,09 \%)$.

Za pozostałe $25,43 \%$ przyczyn odpowiada 5 innych niezgodności tj.: rdza, smugi, brak otworów na kołnierzu, zarysowania kołnierza, zabrudzenia zewnętrzne kołnierza. 


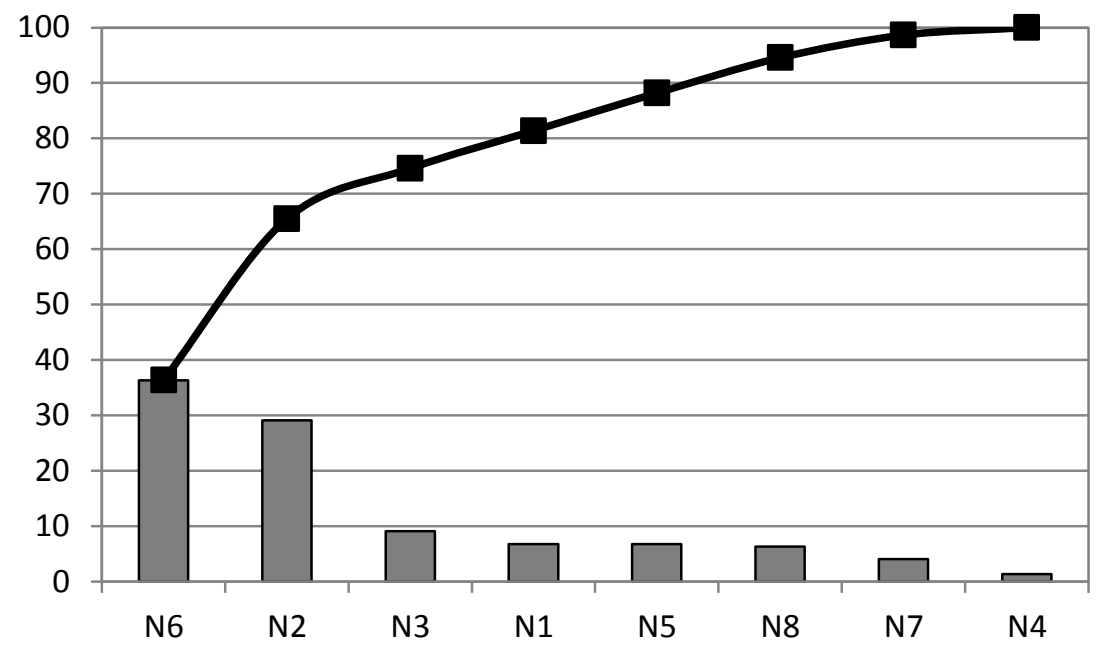

Rys. 3. Wykres Pareto-Lorenza dla niezgodności występujących w procesie produkcji tlumika drgań skrętnych w przedsiębiorstwie branży motoryzacyjnej Źródto: opracowanie własne

Przedsiębiorstwo powinno zwrócić szczególną uwagę, na jakość dostarczanych części do procesu ponieważ dwie trzecie liczby głównych niezgodności powstaje prawdopodobnie już u dostawcy bądź też podczas transportu części. Warto zwrócić także, na skład produkowanej gumy. Niezgodności związane z tym elementem stanowią największą wartość tj. $36,36 \%$. Skład materiałowy gumy, proces wulkanizacji mogą mieć wpływ na powstawanie owego problemu.

\section{Kwantyfikacja przyczyn niezgodności z wykorzystaniem metody FMEA}

Metoda FMEA ( tzw. analiza przyczyn, skutków i wad) jest jedną z metod zarządzania jakością. Celem metody FMEA jest systematyczna identyfikacja poszczególnych wad produktu lub procesu oraz ich eliminacja lub minimalizacja skutków. Można to osiągnąć przez ustalenie związków przyczynowo skutkowych powstania potencjalnych wad 
produktu przy uwzględnieniu czynników ryzyka. FMEA pozwala na ciągle doskonalenie produktu i procesu poprzez systematyczne przeprowadzanie analiz i wprowadzaniu poprawek, które eliminują źródła wad i poprawiają właściwości wyrobu (BORKOwSKI S., KONSTANCIAK M. 2011).

Analiza FMEA ma bardzo szerokie zastosowanie. Jest skuteczna przy analizie złożonych procesów i produktów, w produkcji masowej i jednostkowej. Analizie można poddać pojedynczy komponent oraz podzespół jak i cały wyrób, fragment procesu (np. jedną operację) oraz cały proces technologiczny. Na podstawie wyników można wprowadzić poprawki i nowe rozwiązania po to by wyeliminować źródła wad. Zgodnie z zasadą ciągłego doskonalenia wprowadza stałe kontrole i nadzór. Tworząc analizę FMEA określono wskaźniki ryzyka wystąpienia błędu, znaczenia dla klienta oraz możliwość wykrycia.

$\mathrm{Na}$ podstawie wzoru na obliczenie LPR (liczby priorytetowej ryzyka), $\mathrm{LPR}=\mathrm{Z}^{*} \mathrm{~W}^{*} \mathrm{R}$ wyodrębniono błędy krytyczne dla procesu $\mathrm{i}$ określono działania naprawcze. Działania przedstawiono w tablicy 2.

Z badań wynika, że największy stopień ryzyka wystąpienia wady dotyczy błędu wyszczerbienia gumy ( $L P R=240)$, następną wada na dość wysokim poziomie ryzyka jest nieprawidlowy ksztalt $(\mathrm{LPR}=160)$ ten błąd ma także bardzo wysoki wskaźnik znaczenia dla klienta w skali od 1-10 uzyskał poziom 10. Ważnym wadą dla klienta jest również pęknięcie gumy, które osiągnęło poziom 9. Najmniej występującą wada jest rdza w skali ok. 1-10 posiada wartość 2 i zabrudzenia zewnętrzne, które tym samym czynnikiem zostały określone tą samą wartością (2). Najmniejsza liczbę priorytetową osiągnęła wada rdza $(L P R=36)$. Dwie główne wady przedstawione $\mathrm{w}$ tablicy można $\mathrm{w}$ stosunkowo łatwy sposób wyeliminować wprowadzając proste działania korygująco naprawcze. W przypadku wyszczerbienia gumy wystarczy odpowiednie ustawienie maszyny tnącej gumę, jeśli chodzi o drugą wadę czyli nieprawidłowy kształt odnosi się do dostawcy, który prawdopodobnie będzie musiał wymienić formę odlewu. Zadaniem przedsiębiorstwa 
będzie przeprowadzanie częstszej kontroli wejściowej części przyjmowanych od tego dostawcy.

Tablica 2. Rodzaje wystęujących wad w przedsiębiorstwie

\begin{tabular}{|c|c|c|c|c|c|c|c|c|}
\hline $\begin{array}{c}\text { Rodzaj } \\
\text { błędu }\end{array}$ & $\begin{array}{l}\text { Skutki } \\
\text { błędu }\end{array}$ & $\begin{array}{c}\text { Przyczyny } \\
\text { błędu }\end{array}$ & $\begin{array}{c}\text { Podejmowa } \\
\text { ne środki } \\
\text { kontrolne }\end{array}$ & $\mathbf{Z}$ & $\mathbf{W}$ & $\mathbf{R}$ & LPR & $\begin{array}{c}\text { Dzialania } \\
\text { naprawcze }\end{array}$ \\
\hline Rdza & $\begin{array}{c}\text { Nie } \\
\text { odpowiedni } \\
\text { e warunki } \\
\text { fizyczne }\end{array}$ & $\begin{array}{c}\text { Złe } \\
\text { warunki } \\
\text { przechowy } \\
\text { wania }\end{array}$ & $\begin{array}{c}\text { Zwiększenie } \\
\text { kontroli } \\
\text { wejściowej }\end{array}$ & 9 & 2 & 2 & 36 & $\begin{array}{l}\text { Zabezpiecz } \\
\text { enie części }\end{array}$ \\
\hline $\begin{array}{l}\text { Nieprawidł } \\
\text { owy kształt }\end{array}$ & $\begin{array}{c}\text { Nieodpowi } \\
\text { ednia forma } \\
\text { kształtu } \\
\text { wyrobu }\end{array}$ & \begin{tabular}{|c|} 
Źle \\
wykonana \\
forma
\end{tabular} & $\begin{array}{c}\text { Kontrola } \\
\text { wizualna } \\
\text { 5szt./60szt. }\end{array}$ & 10 & 2 & 8 & 160 & $\begin{array}{c}\text { Wykonanie } \\
\text { odpowiedn } \\
\text { iej formy } \\
\text { wg. } \\
\text { zaleceń }\end{array}$ \\
\hline $\begin{array}{l}\text { Pęknięcie } \\
\text { gumy }\end{array}$ & $\begin{array}{l}\text { Osłabienie } \\
\text { materiału }\end{array}$ & $\begin{array}{c}\text { Zły dobór } \\
\text { składnikó } \\
\text { w gumy }\end{array}$ & $\begin{array}{c}\text { Badania } \\
\text { laboratoryjn } \\
\text { e. }\end{array}$ & 9 & 3 & 4 & 108 & $\begin{array}{l}\text { Zmiana } \\
\text { składników } \\
\text { mieszanki } \\
\text { gumowej }\end{array}$ \\
\hline $\begin{array}{c}\text { Zabrudzeni } \\
\text { a } \\
\text { zewnętrzne } \\
\text { kołnierza }\end{array}$ & $\begin{array}{l}\text { Wpływ na } \\
\text { dalsze } \\
\text { działania } \\
\text { procesu }\end{array}$ & $\begin{array}{c}\text { Złe } \\
\text { warunki } \\
\text { przechowy } \\
\text { wania }\end{array}$ & $\begin{array}{c}\text { Kontrola } \\
\text { wizualna } \\
\text { 5szt./60szt. }\end{array}$ & 5 & 5 & 2 & 50 & $\begin{array}{l}\text { Zabezpiecz } \\
\text { enie części }\end{array}$ \\
\hline $\begin{array}{l}\text { Wyszczerbi } \\
\text { enia gumy }\end{array}$ & $\begin{array}{c}\text { Osłabienie } \\
\text { materiału, } \\
\text { zmiana } \\
\text { właściwośc } \\
\text { i }\end{array}$ & $\begin{array}{l}\text { Zła praca } \\
\text { maszyny }\end{array}$ & $\begin{array}{l}\text { Kontrola } \\
\text { wizualna }\end{array}$ & 8 & 5 & 6 & 240 & $\begin{array}{l}\text { Naprawa } \\
\text { maszyny }\end{array}$ \\
\hline
\end{tabular}

Źródło: opracowanie własne 


\section{Propozycja doskonalenia procesu}

Badanie potrzeb klientów jest działaniem jednym $\mathrm{z}$ wielu, zmierzającym do rozwoju i doskonalenia przedsiębiorstwa. Przedsiębiorstwo posiadając informacje o oczekiwaniach odbiorców do nich dostosuje swoje działania. Cały system produkcyjny przedsiębiorstwa funkcjonuje, aby ostatecznie wyrób sprzedać klientowi. Dlatego ważnym jest aby dany wyrób spełniał wymogi klienta i był konkurencyjny na rynku. Odpowiednia wiedza na ten temat pozwoli osiągnąć firmie spełnienie wymagań odbiorców i sprawi, że dany produkt będzie konkurencyjny. Produkcja zgodnie z oczekiwaniami, powoduje osiągnięcie satysfakcji odbiorców, sprzedaż wyrobów, a tym samym zwiększenie zysków, dzięki czemu firma może się rozwijać (BORKOWSKI S. 2010).

Metoda zarządzania jakością, która służy do przełożenia wymagań klienta na odpowiednie cechy produktu (usługi) na każdym etapie jego cyklu życia, począwszy od badań i rozwoju poprzez projektowanie i produkcję, aż po marketing, sprzedaż i dystrybucję, jest metoda QFD. Metoda ta angażuje wszystkie funkcje przedsiębiorstwa i jest stosowana w celu zapewnienia, przez wszystkie fazy rozwoju wyrobu (od idei po dostawy), dopóki wymagania klienta nie zostaną spełnione. QFD można więc uważać za metodę planowania i rozwoju projektu lub usługi, umożliwiającą zespołom badawczym dokonanie precyzyjnej specyfikacji potrzeb i wymagań klientów, a następnie ich przełożenia na parametry produktu (usługi), jego komponentów i wreszcie parametry samego procesu produkcyjnego (BORKOWSKI S. 2012, LIKER J. K. 2005).

Zadaniem metody QFD jest odpowiedź na następujące pytanie:

- jakie są wymagania (oczekiwania) klientów?

- jak te wymagania spełnić?

Odpowiedzi na powyższe pytania są zapisywane za pomocą macierzy zwanej Domem Jakości przedstawionym na rys. 4.

Metoda QFD porządkuje zebrane przyczyny - potrzeby klientów, a następnie określa ważność dla niego danego czynnika w skali od 1 do 10, gdzie 1 oznacza nieważne, a 10 - bardzo ważne. Określany jest 
Zeszyty Naukowe

również profil przedsiębiorstwa w stosunku do konkurencji w skali 1, 3 i 5 gdzie 1 - spełnienie słabe, 3 - przeciętne, 5 - bardzo dobre.

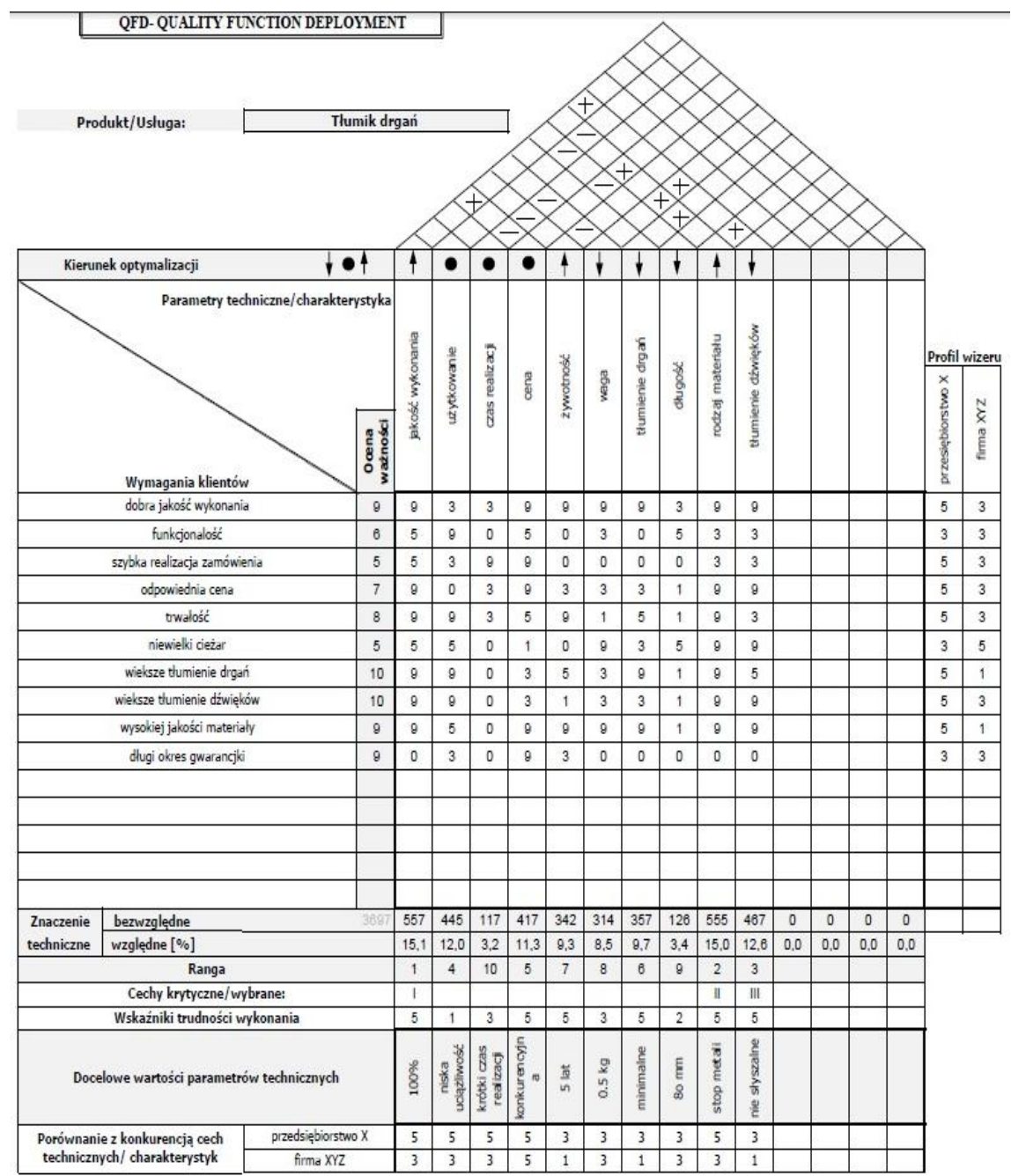

Rys. 3. Dom jakości dla tlumika drgań

Źródto: opracowanie własne 
Należy zauważyć, że tworząc Dom Jakości wpisujemy również zależność między parametrami technicznymi a wymaganiami klientów w postaci liczbowej tzn.9 - zależność bardzo silna, 5- zależność silna, 3 zależność średnia, 1 - zależność słaba. Jeśli nie ma powiązania między parametrami wpisywane zostało 0 . Na podstawie wyników określane są cechy krytyczne, którymi w pierwszej kolejności przedsiębiorstwo powinno się zająć. $Z$ powyższego zestawienia wynika, iż cechami krytycznymi są: jakość wykonania, rodzaj materiatu oraz ttumienie dźwięków.

Jakość wykonania - w proponowanym produkcie planuje się zastosowanie najlepszych technik łączenia elementów oraz wulkanizacji elementów wykonanych z gumy. Firma planuje zakup nowoczesnych maszyn zapewniających wysoką jakość wykonania. Pozwoli on na zaspokojenie najwięcej znaczących dla klienta wymagań odnośnie produktu.

Drugą istotnym cechą jest rodzaj materiału. Przedsiębiorstwo wykorzystuje wysokiej jakości materiały. Dodatkowo trwają badania nad opracowaniem nowego stopu, który będzie bardziej wytrzymały, lżejszy, thumiący drgania $i$ hałas. To rozwiązanie techniczne da dużą przewagę nad konkurencją.

Trzecią cechą jest thumienie dźwięków. Ważne jest aby element tłumił dźwięki wydostające się z silnika, tak aby nie były odczuwalne podczas jazdy samochodem. W tym celu stosuje się odpowiedni materiał aby zminimalizować je do zera.

\section{Podsumowanie}

W obecnych czasach, każde przedsiębiorstwo stara się produkować wysokiej jakości produkty tak aby spełnić wymagania klienta (odbiorcy). W celu uzyskania najwyższej jakości stosuje się rozmaite metody i narzędzia, które będą wspomagać, kontrolować proces produkcyjny. Przemysł samochodowy wymaga od producentów najwyższej jakości produktów. Tylko dzięki starannemu podejściu do jakości można spełnić wymagania klienta i stać się konkurencyjnym przedsiębiorstwem. 
Wyniki uzyskane na podstawie diagramu Ishikawy wskazują, iż należy zacząć działania eliminujące potencjalne przyczyny od obszaru metoda i materiał. Problemem największym jest nie stosowanie się do procedur jakie obowiązują w przedsiębiorstwie. Spowodowane jest to nieuwagą, brakiem czasu pracownika oraz brakiem odpowiednich szkoleń umożliwiających podniesienie kwalifikacji pracownika.

Diagram Pareto - Lorenza wskazał dwie przyczyny, które w najistotniej wpływają na jakość produkowanych części. Wyeliminowanie takich wad jak: pęknięcia gumy i pęcherzyki na kotnierzach spowoduje zmniejszenie wadliwości wyrobu o ok. 65\%.

Metoda FMEA wykazała, iż największym błędem krytycznym są wyszczerbienia gumy wyrobu, co świadczy, iż najpoważniejszy błąd występuje podczas wycinania odpowiednich kształtów. Uzyskane wyniki wskazały że maszyna wykrawająca nie działa poprawnie. Dane o nieprawidłowej pracy maszyny należy przekazać do kierownika produkcji w celu naprawy i wyeliminowania błędu.

Na podstawie uzyskanych wyników, należy stworzyć i wprowadzić odpowiedni system poprawy jakości. Wyniki dotyczące jakości produkcji części samochodowych wskazują, iż należy znaleźć źródło problemu, podjąć działania korygujące oraz zapobiegawcze. Proces produkcyjny należy ciągle doskonalić. Najprostszym sposobem jest stosowanie elementów filozofii Kaizen. Doskonalenie małymi krokami, standaryzacja procesów, wykorzystując pomysły, informacje, wiedzę, doświadczenie od wszystkich pracowników. Zastosowanie metody QFD wskaże rangę ważności potrzeb klienta. Zwróci uwagę na najważniejsze elementy, określi ważność dla niego danego czynnika oraz zwróci uwagę na profil przedsiębiorstwa w stosunku do konkurencji. Na podstawie wyników określane są cechy krytyczne, którymi w pierwszej kolejności przedsiębiorstwo powinno się zająć.

\section{Literatura}

1. BORKOWSKI S. 2004. Mierzenie poziomu jakości. Wydawnictwo Wyższa Szkoła Zarządzania i Marketingu w Sosnowcu. Sosnowiec. 
2. BORKOWSKI S. 2010. Zasady zarzadzania TOYOTY $w$ pytaniach, Wyniki Badań BOST, Wydawnictwo Menedżerskie PTM, Warszawa.

3. BoRKOWSKI S. 2012. Toyotaryzm. Wyniki badań BOST. Oficyna PTM. Warszawa

4. BORKOWSKI S., KLIMECKA-TATAR D., KRYNKE M. 2012. Reliability of Technology in the Manufacture of Automotive Parts. Quality and Reliability of Technical Systems. Zbornik vedeckych prac. Vyd. Slovenska pol'nohospodarska univerzita v Nitre. Nitra. s. 296-300.

5. BorkowsKi S., KonstanciaK M. 2011. Production Improvement. Editing and Scientific Elaboration Borkowski S., Konstanciak M., Publish. TRIPSOFT, Trnava.

6. BORKOWSKI S., UlEWICZ R. 2008. Zarzadzanie produkcja, systemy produkcyjne. Wydawnictwo Humanitas. Sosnowiec.

7. LIKER J. K. 2005. Droga Toyoty. 14 zasad zarzadzania wiodacej firmy produkcyjnej świata, Wydawnictwo MT Biznes, Warszawa.

8. ŁUNARSKI J. 2008. Zarządzanie jakościa.Standardy i zasady, wyd, Naukowo-Techniczne, Warszawa.

9. PN-EN ISO 9001:2009 - Systemy zarzadzania jakościa Wymagania. Polski Komitet Normalizacyjny, Warszawa 2009.

10. StabryŁa A. 1998. Podstawy zarzadzania firma, Wydawnictwo ANTYKWA, Kraków. 